\title{
HESITATIONS ABOUT SPECIAL DIVINE ACTION: REFLECTIONS ON SOME SCIENTIFIC, CULTURAL AND THEOLOGICAL CONCERNS
}

\author{
ALISTER E. MCGRATH \\ Oxford University
}

\begin{abstract}
The new interest in special divine action has led to a close reading of the great debates and discussions of the early modern period in an attempt to understand contemporary resistance to the notion of divine action, and to develop strategies for reaffirming the notion in a refined manner. Although continuing engagement with and evaluation of the Humean legacy on miracles and divine action will be of central importance to this programme of review, there are other issues that also need to be addressed. In this article I identify some of the factors that have caused or continue to cause difficulties for the articulation of a concept of special divine action and I suggest how they might be engaged.
\end{abstract}

The last two decades have witnessed a renewed surge of interest in the question of whether, and to what extent, God may be said to act in the world. Can God be understood to act entirely in and through the regular structures and capacities of nature, or does a robust account of divine action also require us to affirm that God acts specially in order to redirect the course of events in the natural world, thus delivering outcomes that would not have occurred if God had not acted in this way? Although this discussion is sometimes framed in terms of a generic notion of divinity, ${ }^{1}$ the most significant recent engagements with the question have reflected Judeo-Christian conceptions of God, and the questions arising from these.

The language of divine action is integral to both Old and New Testaments. The God of Israel is regularly and definitively depicted and

\footnotetext{
${ }^{1}$ See, for example, Jeffrey Koperski, The Physics of Theism: God, Physics, and the Philosophy of Science (New Malden, MA: Wiley-Blackwell, 2015), pp. 146-65.
} 
described as a God who acts in history. ${ }^{2}$ God's identity and character are understood to be made visible in the sphere of human action and reflection. ${ }^{3}$ This concentration on God's actions in nature and history could lead to the neglect of important themes (such as the more subtle unobtrusive forms of divine activity in everyday experience), as well as creating an essentially impersonal notion of God as a spiritual force. ${ }^{4}$ Yet despite these important qualifications, Israel understood and represented God as one who acted in nature and in history. ${ }^{5}$ The New Testament maintains this tradition, and focuses it on the life, death and resurrection of Jesus of Nazareth. ${ }^{6}$

So how do we account for this resurgence of interest in the question of divine activity? One factor is the increasing awareness of the inadequacy of the theologies of the 1960s to accommodate this notion. The noted theologian and philosopher Ian T. Ramsey (1915-72) was alarmed at the failure of the 1960s to recognize the importance of affirming divine activity. To lose sight of this central theme, he argued, was to drift into a theological atheism. ${ }^{7}$ There was a need for 'justified talk of God's activity' if the situation was to be retrieved. Process thought began to emerge around this time as a potential solution to this dilemma, offering an approach to divine activity which seemed to meet at least some of the inadequacies of the regnant neo-Orthodoxy within Protestantism. ${ }^{8}$

${ }^{2}$ For a good review of the primary and secondary sources on this point, see Terence E. Fretheim, 'The God Who Acts: An Old Testament Perspective', Theology Today, 54 (1997), 6-18.

${ }^{3}$ The narrative of God's action is thus seen as disclosing or 'rendering' God's character: see, for example, David Kelsey, The Uses of Scripture in Recent Theology (Philadelphia: Fortress, 1975), pp. 39-50.

${ }^{4}$ See the comments in Fretheim, 'The God Who Acts', p. 7. For a detailed examination of one such instance of divine action, see William Stacy Johnson, 'God's Ordering, Providing, and Caring for the World', Theology Today, 54 (1997), 29-42.

${ }^{5}$ For an analysis, see William Paul Griffin, The God of the Prophets: An Analysis of Divine Action (Sheffield: Sheffield Academic Press, 1997), pp. 76-191.

${ }^{6}$ See, for example, N. T. Wright, The Resurrection of the Son of God (London: SPCK, 2003), pp. 20-8; Richard Cross, The Metaphysics of the Incarnation: Thomas Aquinas to Duns Scotus (Oxford: Oxford University Press, 2005), pp. 152-5; Kevin J. Vanhoozer, Remythologizing Theology: Divine Action, Passion, and Authorship (Cambridge: Cambridge University Press, 2010), pp. 33-80; Denis Edwards, How God Acts: Creation, Redemption, and Special Divine Action (Minneapolis: Fortress Press, 2010), pp. 57-141.

7 Ian T. Ramsey, Models for Divine Activity (London: SCM Press, 1973), pp. 56-66.

${ }^{8}$ Gary J. Dorrien, The Making of American Liberal Theology: Crisis, Irony, and Postmodernity, 1950-2005 (Louisville, KY: Westminster John Knox Press, 2006), p. 204. 
Modern Pentecostal theologians have developed theories of divine action within the world based on the complex activity of the Holy Spirit, which ultimately transcends frameworks of interpretation. ${ }^{9}$ Other readings of the Christian tradition which offer an illuminating engagement with the theme of divine action include Thomist accounts of God's agency in nature, which have been widely applied to physical and biological processes. ${ }^{10}$ Recent accounts of Aquinas's concept of causality suggest that, while some questions need to be addressed, this is likely to remain a fertile field of exploration in the near future. ${ }^{11}$

The extended project of interdisciplinary conferences and publications entitled 'Scientific Perspectives on Divine Action' (1988-2003) is a particularly good example of this renewed interest in the notion of divine action. This project - generally referred to simply as the 'Divine Action Project' [DAP] - brought together scholars from the fields of natural science, philosophy, and theology in a sustained discussion over a period of fifteen years to consider whether the notion of divine action remained meaningful and defensible. Important though this project may have been, particularly in identifying and evaluating possibilities, its constructive outcomes remain unclear, even elusive, as may be seen from the concerns expressed in a retrospective volume published to mark the formal end of the project. ${ }^{12}$ There is clearly a need for further exploration

For further discussion, see David Ray Griffin, Reenchantment Without Supernaturalism: A Process Philosophy of Religion (Ithaca, NY: Cornell University Press, 2001).

${ }^{9}$ Amos Yong, The Spirit of Creation: Modern Science and Divine Action in the Pentecostal-Charismatic Imagination (Grand Rapids, MI: Eerdmans, 2011), pp. 72-137. Ramsey also notes the importance of such Spirit-based approaches: Ramsey, Models for Divine Activity, pp. 1-14.

${ }^{10}$ Armand Maurer, 'Darwin, Thomists, and Secondary Causality', Review of Metaphysics, 57 (2004), 491-515; William E. Carroll, 'Divine Agency, Contemporary Physics, and the Autonomy of Nature', Heythrop Journal, 49 (2008), 582-602. For contemporary critiques of the idea of secondary causality, see Alfred J. Freddoso, 'Medieval Aristotelianism and the Case against Secondary Causation in Nature', in Divine and Human Action: Essays in the Metaphysics of Theism, ed. by Thomas V. Morris (Ithaca, NY: Cornell University Press, 1988), pp. 74-118. For early modern concerns about such notions of causality, see J. A. van Ruler, The Crisis of Causality: Voetius and Descartes on God, Nature, and Change (Leiden: Brill, 1995), pp. 107-66.

${ }^{11}$ See especially Michael J. Dodds, Unlocking Divine Action: Contemporary Science \& Thomas Aquinas (Washington, DC: Catholic University of America Press, 2012).

${ }^{12}$ Robert John Russell, Nancey Murphy, and William R. Stoeger, S.J., eds. Scientific Perspectives on Divine Action: Twenty Years of Challenge and Progress (Vatican City State: Vatican Observatory, and Berkeley, CA: Center for Theology and the Natural Sciences, 
of the issues. Since the affirmation of the existence of God does not entail that this God should act in any way - whether 'special' or 'general' - this article will focus on the specific question of God's activity, not the more general (and quite distinct) question of God's existence.

A central theme of recent discussions of special divine action has been the reassessment of David Hume's arguments against miracles. It is well known that there are difficulties with these arguments - such as the problematic definition of the term 'miracle', Hume's limiting conception of a law of nature, and his somewhat unconvincing description of the evidence for natural laws and the role of historical testimony. ${ }^{13}$ These revisionary readings of Hume, particularly when taken in conjunction with the criticisms of Hume developed by his contemporaries, are likely to create an intellectual environment more hospitable to the notion of special divine action.

So how is the notion of divine action to be sustained, in the light of multiple suspicions of the notion on the one hand, and continuing interest in it on the other? There is no doubt of this interest and commitment, and of the willingness on the part of scholars to engage the issues at stake, including the important question of whether the conventional distinction between 'general divine action' and 'special divine action' can be maintained. ${ }^{14}$

2008). For an assessment of the project, see Wesley J. Wildman, 'The Divine Action Project, 1988-2003', Theology and Science, 2 (2004), 31-75; F. LeRon Shults, Nancey C. Murphy, and Robert J. Russell, Philosophy, Science and Divine Action (Leiden: Brill, 2009); Leigh C. Vicens, 'On the Possibility of Special Divine Action in a Deterministic World', Religious Studies, 48 (2012), 315-36. Vicens' analysis should be read alongside the earlier reflections of Arthur R. Peacocke, 'God's Interaction with the World: The Implications of Deterministic "Chaos" and of Interconnected and Interdependent Complexity', in Chaos and Complexity: Scientific Perspectives on Divine Action, ed. by Robert J. Russell, Nancey Murphy and Arthur R. Peacocke (Vatican City State: Vatican Observatory, and Berkeley, CA: Center for Theology and the Natural Sciences, 1995), pp. 263-88.

${ }^{13}$ John Earman, Hume's Abject Failure (Oxford: Oxford University Press, 2000). For a response, see Robert J. Fogelin, A Defense of Hume on Miracles (Princeton, NJ: Princeton University Press, 2003); Peter Millican, 'Earman on Hume on Miracles', in Debates in Modern Philosophy: Essential Readings and Contemporary Responses, ed. by Stewart Duncan and Antonia LoLordo (New York: Routledge, 2013), pp. 271-84. See also Aviezer Tucker, 'Miracles, Historical Testimonies, and Probabilities', History and Theory, 44 (2005), 373-90; Graham H. Twelftree, ed., The Cambridge Companion to Miracles (Cambridge: Cambridge University Press, 2009).

${ }^{14}$ See especially the concerns noted in Niels H. Gregersen, 'Special Divine Action and the Quilt of Laws: Why the Distinction between Special and General Divine Action 
This article identifies some of the chief concerns that underlie resistance to the notion of 'special divine action', and reflects on how these can be engaged. Although these concerns can be allocated to the broad categories of culture, the natural sciences, and theology, these boundaries are porous and poorly defined and policed. While the importance of philosophical arguments for the topic under consideration will be obvious, this article will focus on three additional fields which have in the past raised certain difficulties for the notion of special divine action: culture, the natural sciences, and Christian theology.

\section{CULTURAL CONCERNS ABOUT SPECIAL DIVINE ACTION}

The notion of special divine action caused relatively little mental discomfort in the Middle Ages and Renaissance; indeed, the notion of special divine action in healing or other miraculous events lay at the heart of much popular religion of the age. ${ }^{15}$ In England, Catholic attempts to rebuff the growing influence of Protestantism were often linked with an appeal to miracles wrought by saints or through relics as a sign of God's presence and favour. ${ }^{16}$ Yet this would gradually give way to a marked cultural disinclination to take the notion of special divine action seriously, discounting this as superstition or the vestiges of an outdated popular religiosity which had no place in the modern world. One of the reasons for the rise of 'natural theology' in British Protestant religious thought of the late seventeenth and eighteenth centuries was the presumption that God did not act directly within nature, but that God's wisdom in creation - understood as a past event - could be seen from an intelligent and committed study of the world of nature. ${ }^{17}$ The natural theology of the modern age offered an apologetic for faith based on the assumption that God had acted in the past, reflecting a growing

Cannot Be Maintained, in Scientific Perspectives on Divine Action: Twenty Years of Challenge and Progress, pp. 179-99. There are some interesting parallels here with the distinction between 'general' and 'special' revelation in systematic theology, which cannot be explored further here: for these concepts, see Gerald O'Collins, Rethinking Fundamental Theology (Oxford: Oxford University Press, 2011), pp. 56-92.

${ }^{15}$ Jane Shaw, Miracles in Enlightenment England (New Haven, CT: Yale University Press, 2006).

16 Alexandra Walsham, 'Miracles and the Counter Reformation Mission to England', Historical Journal, 46 (2003), 779-815.

17 Alister E. McGrath, Darwinism and the Divine: Evolutionary Thought and Natural Theology (Oxford: Wiley-Blackwell, 2011), pp. 56-74. 
cultural disinclination to believe in direct divine action in the present. ${ }^{18}$ The philosopher Charles Taylor rightly asks how this transition is to be explained. 'Why was it virtually impossible not to believe in God in, say, 1500 in our Western society, while in 2000 many of us find this not only easy, but even inescapable?'19 Taylor's answer is presented in terms of the social dominance of a cluster of modern prejudices which he designates 'The Immanent Frame. This cultural metanarrative weaves together a number of themes, including the disenchantment of the world, an understanding of nature as an impersonal order, the rise of an 'exclusive humanism', and an ethics which is framed primarily in terms of discipline, rules, and norms.

Taylor notes that this 'exclusive humanism' advocates a view of human flourishing which denies or suppresses any notion of a transcendent source of morality, such as God or the Tao, and which refuses to recognize any good beyond this life and world. The outcome of the dominance of this narrative is the cultural exclusion of a transcendent reality in general, particularly the notion of a God who can be considered to act within the world. For Taylor, contemporary understandings of human flourishing, the natural order, and the moral life, and nature are all framed in a selfsufficient, naturalistic, and immanent manner. ${ }^{20}$

Being rational now comes to mean taking some distance from ordinary, embodied human existence and striving to acquire mastery over the self and the world. The disengagement that this involves is mental or intellectual; the mind tries to prescind from its involvement in ordinary existence and aspires to a more detached, disinterested perspective on the world.

${ }^{18}$ A good example is William Paley's Evidences of Christianity (1794), which affirms the apologetic and evidential importance of miracles in the apostolic period, but without any expectation that they recur outside that era. Paley's rebuttal of David Hume's critique of miracles in this work merits close study, especially in relation to the theme of 'special divine action'. See, for example, Michael J. McClymond, Encounters with God: An Approach to the Theology of Jonathan Edwards (Oxford: Oxford University Press, 1998), pp. 85-8.

${ }^{19}$ Charles Taylor, A Secular Age (Cambridge, MA: Belknap Press, 2007), p. 25. For assessments of Taylor's approach, see Michael Warner, Jonathan VanAntwerpen, and Craig J. Calhoun, eds., Varieties of Secularism in a Secular Age (Cambridge, MA: Harvard University Press, 2010); Carlos D. Colorado, and Justin D. Klassen, eds., Aspiring to Fullness in a Secular Age: Essays on Religion and Theology in the Work of Charles Taylor (Notre Dame, IN: University of Notre Dame Press, 2014).

${ }^{20}$ Charles Taylor, Sources of the Self: The Making of the Modern Identity (Cambridge, MA: Harvard University Press, 1989), p. 149. 
Echoes of Taylor's analysis can be found in older critics of western culture. For example, C. S. Lewis's writings of the 1940s show a growing anxiety over signs that the category of the transcendent was being intentionally sidelined within English intellectual life. His Abolition of Man (1943) noted how the educational system of the day seemed designed to eradicate any intuitions of transcendence in morality or religion. ${ }^{21}$ The sermon 'The Weight of Glory' (1941) asserts that people are now held spellbound, caught up in a secular and secularising metanarrative that insists that human destiny and good lie in this world alone. We are told and come to believe - that the ideas of transcendent realms, of worlds to come, are simply illusions. The educational system, Lewis notes with obvious sadness, has colluded with the modern myth that the sources and goals of human good are 'found on this earth.'22

Lewis declares that the time has come to break free from this 'evil enchantment of worldliness'. Lewis has no doubt about what has to be done. So deeply has this 'evil enchantment' saturated English culture that the 'strongest spell' is needed if its power is to be broken. Lewis reminds his readers that 'spells are used for breaking enchantments as well as for inducing them'. For Lewis, Christianity has to show that it can tell a more compelling and engaging story that will capture the imagination of its culture. In the end, of course, Lewis provided such a counter-narrative in his Chronicles of Narnia.

Taylor's point is that the culture of our 'secular age' now makes a sharp distinction between the natural and the supernatural, the human and the divine, so that making sense of the world around us now seems to be possible in terms of this world alone. Nature became emptied of the spirits, signs, and cosmic purposes that once seemed a fact of everyday experience. It came to be conceived fundamentally as an impersonal order of matter and force, governed by causal laws, making the notion of special divine action counterintuitive, if not conceptually incredible. Taylor notes the importance of Weber's concept of the 'disenchantment of nature, ${ }^{23}$ while offering his own reinterpretation of this in terms of

${ }^{21}$ Michael D. Aeschliman, The Restitution of Man: C. S. Lewis and the Case against Scientism (Grand Rapids, MI: Eerdmans, 1998).

${ }^{22}$ C. S. Lewis, Essay Collection (London: HarperCollins, 2002), p. 99.

${ }^{23}$ On which see Michael T. Saler, 'Modernity, Disenchantment, and the Ironic Imagination', Philosophy and Literature, 28 (2004), 137-49; Alison Stone, 'Adorno and the Disenchantment of Nature', Philosophy \& Social Criticism, 32 (2006), 231-53. 
'disengagement.' ${ }^{24}$ There has been a marked shift to 'Closed World Structures' that tacitly accept 'the immanent frame' as normative, seen in the fact that most people no longer see natural events as acts of God. ${ }^{25}$ Nature has become reduced to the predictable and quantifiable. For Taylor, this means that the dominant cultural narrative leaves no place for the 'vertical' or 'transcendent', but in one way or another closes these off, renders them inaccessible, or even unthinkable. 'Closed World Structures' now function as unchallenged axioms in western culture.

Taylor here describes a cultural predisposition, an axiomatic way of seeing and conceiving the world, which simply excludes the notion of special divine action as a matter of principle. This notion is now deemed 'unthinkable'; to run counter to this cultural mindset is a symptom of a fundamental irrationality. So what can be done about it? How can this cultural narrative be challenged? Taylor's response is complex, and rests partly on understanding how this narrative achieved social dominance in the first place. It involves grasping an alternative 'master narrative', one of several 'broad framework pictures of how history unfolds' which helps us understand how 'disenchantment' led to the elimination of the transcendent. ${ }^{26}$

In exploring these issues, Taylor sets out an account of secularization which has analytical, phenomenological, and genealogical components. ${ }^{27}$ Taylor's account of the historical origins of this 'master narrative' emphasises its historical contingency. 'It is a crucial fact of our present spiritual predicament', he declares, 'that it is historical; that is, our understanding of ourselves and where we stand is partly defined by our

${ }^{24}$ Luc van den Berge and Stefan Ramaekers, 'Figures of Disengagement: Charles Taylor, Scientific Parenting, and the Paradox of Late Modernity', Educational Philosophy and Theory, 64 (2014), 607-25.

${ }^{25}$ For a succinct account of this notion, see Charles Taylor, 'Geschlossene Weltstrukture in der Moderne', in Wissen und Weisheit: Zwei Symposien zu Ehre von Josef Pieper, ed. by Hermann Fechtrup, Friedbert Schulze and Thomas Sternberg (Münster: LIT Verlag, 2005), pp. 137-69. Taylor's reflections should be set alongside Alvin Plantinga's comments about the problems of framing divine action within a 'Laplacean' paradigm, which assumes 'the causal closure of the universe': Alvin Plantinga, 'What is "Intervention"?', Theology and Science, 6 (2008), 369-401.

${ }^{26}$ Charles Taylor, A Secular Age, p. 573.

${ }^{27}$ For comment, see José Casanova, 'A Secular Age: Dawn or Twilight?', in Varieties of Secularism in a Secular Age, ed. by Michael Warner, Jonathan VanAntwerpen and Craig J. Calhoun (Cambridge, MA: Harvard University Press, 2010), pp. 243-64. 
sense of having come to where we are, of having overcome a previous condition. ${ }^{28}$

Taylor's innovative and engaging account of how this cultural mindset developed questions the validity of what he terms 'subtraction stories', understood as 'stories of modernity in general, and secularity in particular, which explain them by human beings having lost, or sloughed off, or liberated themselves from certain earlier, confining horizons, or illusions, or limitations of knowledge. ${ }^{29}$ For those committed to 'subtraction stories', divine action and transcendence belong to the past, and have no place in the present or future. For Taylor, however, the western mindset remains open to the notions of transcendence and divine action; the problem is that it is not perceived to be so. Taylor's account of the emergence of a 'secular age' emphasises the constitutive God-reference that still 'haunts' the secular age.

A similar point was made by the Polish philosopher Leszek Kolakowski (1927-2009). 'God's unforgettableness', Kolakowski argued, 'means that $\mathrm{He}$ is present even in rejection. ${ }^{30}$ Developing this point further, Kolakowski suggests that the 'return of the sacred' is a telling sign of the failure of the ersatz Enlightenment 'religion of humanity', in which a deficient 'godlessness desperately attempts to replace the lost God with something else.' Taylor concurs, arguing that this persistence of a God-reference should not be seen as an empty vestige, a dead metaphor, but rather as a sign that interest in the transcendent remains embedded within culture, and has the potential for future development.

Taylor's analysis is intended to hold up a mirror to our present, allowing us to discern its regnant implicit narrative - the 'immanent frame' - and grasp that this can be understood as both 'closed' and 'open'. The outcomes of this 'immanent frame' are thus not determined by the frame itself, but by how we choose to interpret and apply it. Taylor opts for an 'open' interpretation of the 'immanent frame', where Weber endorses a 'closed' reading. Both are defensible interpretations (or 'spins') of the

${ }^{28}$ Charles Taylor, A Secular Age, p. 29.

${ }^{29}$ Charles Taylor, A Secular Age, p. 22.

${ }^{30}$ Leszek Kolakowski, 'Concern about God in an Apparently Godless Age', in $M y$ Correct Views on Everything, ed. by Zbigniew Janowski (South Bend, IN: St. Augustine's Press, 2005), pp. 173-83 (p. 183). For further reflections on Kolakowski's significance, see Alister E. McGrath, 'Atheism and the Enlightenment: Reflections on the Intellectual Roots of the "New Atheism"', in Mere Theology: Christian Faith and the Discipleship of the Mind (London: SPCK, 2010), pp. 139-54. 
'immanent frame'; both, however, are to be seen as acts of faith, in that neither are demanded by this frame. ${ }^{31}$

The immanent order can, therefore, slough off the transcendent. But it doesn't necessarily do so. What I have been describing as the immanent frame is common to all of us in the modern West, or at least that is what I'm trying to portray. Some of us want to live it as open to something beyond; some live it as closed. It is something which permits closure, without demanding it.

Taylor thus notes that, as a matter of fact, far from being uniformly antireligious or atheist, Western culture displays 'a whole gamut of positions, from the most militant atheism to the most orthodox traditional theisms, passing through every possible position on the way. ${ }^{32}$

So where does this leave us? What are the implications of Taylor's reflections on the regnant narrative of western culture for special divine action? Taylor helps us to grasp that suspicion of the notion of special divine action rests partly on a dominant cultural narrative, rather than specifically philosophical objections. The 'immanent frame' is the default position for contemporary discussion of these issues; it is shaped, in part, by philosophical considerations, but has developed a plausibility which goes beyond its philosophical roots. It is impossible to debate the issue of divine action without taking account of this cultural predisposition against this notion. 'We have here what Wittgenstein calls a "picture", a background to our thinking, within whose terms it is carried on, but which is often largely unformulated and to which we can frequently, just for this reason, imagine no alternative.'33

If Taylor is right, the plausibility of special divine action is shaped by cultural pressures and imaginative constructions which ultimately transcend the rational arguments which underlie it. The best way of engaging a closed reading of the 'immanent frame' is to provide an imaginatively compelling alternative, which is seen to have rational plausibility. To revert to the language of C. S. Lewis, noted earlier, we need to break the 'spell' of a closed world system, and open up alternative readings of our world - and perhaps that is best done, not by rational argument, but by capturing the cultural imagination with a richer and deeper vision of reality.

${ }^{31}$ Charles Taylor, A Secular Age, p. 544.

${ }^{32}$ Charles Taylor, A Secular Age, p. 556.

${ }^{33}$ Charles Taylor, A Secular Age, p. 549. 


\section{SCIENTIFIC CONCERNS ABOUT SPECIAL DIVINE ACTION}

The debate about special divine action takes place against a framework of scientific discourse, framed in terms of the 'laws of nature', which raise significant Humean concerns about the notion of divine 'interference' with the regular structures of the world. ${ }^{34}$ With the benefit of hindsight, it can now be seen that the important 'Divine Action Project', noted earlier, was haunted by the fear that interventionist approaches to divine action seemed to call into question the validity of the laws of nature. ${ }^{35}$

The 'divine action project' tried to be sensitive to issues of theological consistency. For example, the idea of God sustaining nature and its law-like regularities with one hand while miraculously intervening, abrogating, or ignoring those regularities with the other hand struck most members as dangerously close to outright contradiction. Most participants certainly felt that God would not create an orderly world in which it was impossible for the creator to act without violating the created structures of order.

The concern within the Divine Action Project was to secure an account of divine action in the world that had scientific 'traction', while at the same time maintained maximal continuity with traditional views on God's action within the world. ${ }^{36}$ Three main approaches emerged within the Divine Action Project, as follows. They are not to be considered as mutually exclusive, in that each could be considered to represent a perspective on the question.

(1) Quantum Theory. A number of writers within the DAP - particularly Robert John Russell and George Ellis - argued that special divine action could be conceived as taking place at the quantum level. ${ }^{37}$ God can be

${ }^{34}$ See the influential article by John W. Carroll, 'The Humean Tradition', Philosophical Review, 99 (1990), 185-219. For his mature views, see John W. Carroll, 'Nailed to Hume's Cross', in Contemporary Debates in Metaphysics, ed. by Theodore Sider, John Hawthorne, and Dean W. Zimmerman (Oxford: Blackwell Publishing, 2008), pp. 67-81.

${ }^{35}$ Wesley J. Wildman, 'The Divine Action Project, 1988-2003', Theology and Science, 2 (2004), 31-75; quotation at p. 38. See further Thomas F. Tracy, 'Scientific Perspectives on Divine Action? Mapping the Options', Theology and Science, 2 (2004), 196-201. For a more critical assessment, see Nicholas Saunders, Divine Action and Modern Science (Cambridge: Cambridge University Press, 2002).

${ }^{36}$ Philip Clayton, 'Towards a Theory of Divine Action That Has Traction', in Scientific Perspectives on Divine Action: Twenty Years of Challenge and Progress, pp. 85-110.

${ }^{37}$ For a collection of essays assessing Russell's approach, see Ted Peters and Nathan Hallanger, eds., God's Action in Nature's World (Basingstoke: Ashgate, 2006). 
understood to act in the world by determining quantum events within the ordinary probability patterns, which permit wide variation in their outcomes. Divine action could thus be envisaged in terms of God's micromanagement of otherwise indeterminate quantum processes and events, whose outcomes eventually percolate through to the macroscopic world.

(2) Complexity Approaches. Divine action is here understood as God working in a 'top-down' manner, such as by influencing the boundary conditions of the natural world, or by influencing conscious embodied human beings. Arthur Peacocke was particularly influential in developing the notion of a 'top-down' causality, by which God's intentions and purposes are implemented in the shaping of particular events, or patterns of events, without any abrogation of the laws of nature. ${ }^{38}$

(3) Chaos Theory. John Polkinghorne has championed the potential for chaos theory to illuminate divine action, noting the exquisite sensitivity of chaotic systems to their initial conditions. ${ }^{39}$ Although Polkinghorne recognises the potential of chaos theory as a means of positing metaphysical openness within nature, he cautions that the 'grave and unresolved difficulties of relating quantum theory to chaos theory' cannot be overlooked.

These three models of divine action have achieved prominence in recent discussions of divine action influenced by scientific considerations, and should be set alongside alternatives - such as the Pentecostal and Thomist approaches. There are clearly viable, even fruitful, options open to those wishing to defend the notion of divine action, including special divine action, in a scientific context. But what challenges do such approaches face? Two major issues emerge in discussion, and will be

\footnotetext{
${ }^{38}$ Arthur R. Peacocke, 'God's Interaction with the World: The Implications of Deterministic "Chaos" and of Interconnected and Interdependent Complexity', in Chaos and Complexity. Scientific Perspectives on Divine Action, ed. by Robert J. Russell, Nancey Murphy and Arthur R. Peacocke (Vatican City: Vatican Observatory, 1995), pp. 263-88. See further Taede A. Smedes, Chaos, Complexity, and God: Divine Action and Scientism (Louvain: Peeters, 2004), pp. 107-71. Peacocke earlier advocated an 'embodied' approach to divine causality: Arthur Peacocke, Creation and the World of Science (Oxford: Oxford University Press, 1979), pp. 142-207.

${ }^{39}$ Ignacio Silva, 'John Polkinghorne on Divine Action: A Coherent Theological Evolution', Science and Christian Belief, 24 (2012), 19-30. Polkinghorne's views on this question have shifted over time, but can be studied from John Polkinghorne, 'The Metaphysics of Divine Action', in Chaos and Complexity: Scientific Perspectives on Divine Action, ed. by Robert J. Russell, Nancey Murphy and Arthur R. Peacocke (Vatican City: Vatican Observatory, 1995), pp. 147-56.
} 
considered further in this article: the notion of 'laws of nature' which govern the universe, and the question of how divine action within nature might be recognized empirically.

One of the most fundamental problems facing the notion of 'special divine action' is that this stands in apparent contradiction to the notion of the laws of nature. The Newtonian emphasis on the regularity of nature, particularly when coupled with the growing trend to conceive nature as analogous to the mechanism of a clock, created difficulties for any notion of divine intervention within the natural world. Intervention entailed disruption of the natural order. Isaac Newton thus took the view that miracles - perhaps the most familiar instance of alleged special divine action - were to be considered an impossibility. ${ }^{40}$ Newton had no difficulty with the idea that God has established the 'laws of nature'; he was concerned, however, over the notion that God might break these laws, in what seemed to him to be an act of potential anarchy. The 'laws of nature' thus came to be interpreted as denying causal openness in the structures of nature. ${ }^{41}$

This hostility towards special divine action is clearly mirrored in Newton's religious writings. He regarded accounts of miracles in the early church as 'feigned', and argued that the biblical accounts of miracles were more concerned with the infrequency of their occurrence, rather than their supposed divine origins. ${ }^{42}$ Many theologians of the eighteenth century - such as Jonathan Edwards - regarded Newton's view of the world, and particularly of God as Pantokrator, as subversive of traditional belief, not least because of its seeming inhospitality to any notion of divine action beyond the primordial act of creation. ${ }^{43}$

Yet however distasteful Newton's idea of a fixed order of nature might appear to some theologians, others found it conducive to social stability. Newton's notion of a law-giving God who created a universe which is regulated and governed in a lawlike manner was easily integrated into

${ }^{40}$ Peter Harrison, 'Newtonian Science, Miracles, and the Laws of Nature', Journal of the History of Ideas, 56 (1995), 531-53.

${ }^{41}$ For alternative approaches which retain a degree of causal openness, see Kile Jones, 'Falsifiability and Traction in Theories of Divine Action', Zygon, 45 (2010), 575-89.

${ }^{42}$ For a detailed analysis, see James E. Force, 'Providence and Newton's Pantokrator: Natural Law, Miracles, and Newtonian Science', in Newton and Newtonianism: New Essays, ed. by James E. Force and Sarah Hutton (Dordrecht: Kluwer, 2004), pp. 65-92.

${ }^{43}$ Avihu Zakai, Jonathan Edwards' Philosophy of Nature: The Re-Enchantment of the World in the Age of Scientific Reasoning (London: T \& T Clark, 2010), pp. 163-205. 
social, as much as scientific, thinking. ${ }^{44}$ At a time when England had experienced intense social upheaval in the seventeenth century through the Civil War and the 'Glorious Revolution', Newton's approach seemed to offer a vision of the world in which the regularity of the natural and social orders complemented and reinforced each other. Special divine action was too easily interpreted in terms of divine interruption or dislocation of the settled physical and social order, and came to be associated with a religiously-motivated political radicalism for which eighteenth-century England had no taste. The 'laws of nature' were thus interpreted as denying causal openness in the structures of nature.

Although the 'laws of nature' were primarily conceived in relation to the physical world, writers such as William Paley emphasised the law-like patterns of behaviour observed within the biological world. ${ }^{45}$ Paley's notion of divine action is essentially static, framed in terms of a given, designed, unchanging order to things, established in the past. Charles Darwin's Origin of Species (1859) made use of the notion of the 'laws impressed on matter by the Creator', a theme which was given a significantly higher profile in the second edition of the Origin of Species than in the first. ${ }^{46}$ Darwin's approach at this point led to him being compared to Newton; just as Newton had uncovered the laws governing the worlds of astronomy and physics, so Darwin had uncovered those governing the biological world. ${ }^{47}$

Such conception of the 'laws of nature' implies a causally closed world, within which special divine action is impossible. Yet is this conception right? What if we ought to think of the 'laws of nature' as descriptive, rather than prescriptive ${ }^{48}$ As enumerations of observations, rather than as stipulations of behaviour? The classical conception of science, which became preeminent during the Enlightenment, regarded science as the

${ }^{44}$ Neal C. Gillespie, 'Natural History, Natural Theology, and Social Order: John Ray and the "Newtonian Ideology", Journal of the History of Biology, 20 (1987), 1-49.

${ }^{45}$ John T. Baldwin, 'God and the World: William Paley's Argument from Perfection Tradition - A Continuing Influence', Harvard Theological Review, 85 (1992), 109-20.

${ }^{46}$ John Hedley Brooke, "Laws Impressed on Matter by the Creator"? The Origins and the Question of Religion, in The Cambridge Companion to the "Origin of Species", ed. by Michael Ruse and Robert J. Richards (Cambridge: Cambridge University Press, 2009), pp. 256-74.

${ }^{47}$ John F. Cornell, 'Newton of the Grassblade? Darwin and the Problem of Organic Teleology', Isis, 77 (1986), 405-21.

${ }^{48}$ There is a large literature. A good starting point is Ronald N. Giere, Science without Laws (Chicago: University of Chicago Press, 1999). 
rational pursuit of universal laws of nature. Yet this is being increasingly challenged, not least because of the growing realization of the valueladen particulars of social constructivism which can be seen at work within the scientific enterprise. For some, the 'laws of nature' are to be seen as relations of necessity between universals; ${ }^{49}$ for others, they are generalizations which figure in the most economical true axiomatization of all our observations of the world..$^{50}$ Serious questions arise as to whether the laws of nature can be said to 'govern' anything. ${ }^{51}$

Contemporary debates about the 'laws of nature' have moved beyond Newton's rather limited and limiting notion, all too easily linked to a deist theology and a determinist metaphysics. The regularities of nature can be affirmed without entailing either of these two unsatisfactory beliefs. One might, for example, think of Nancy Cartwright's emphasis on the natural capacities of domain-specific systems, or Peter Lipton's ceteris paribus laws. ${ }^{52}$ Perhaps more importantly, thinking of the 'laws of nature' in regularist rather than necessitarian terms significantly diminishes the difficulties in speaking of special divine action. ${ }^{53}$ 'The validity of most laws - even of a fundamental physical kind - is compatible with the existence of exceptional situations.'54

A second major concern arises from the question of how special divine action is to be recognized. Although this question has been given relatively little attention in recent discussions, ${ }^{55}$ it serves to emphasise the importance of empirical observation in relation to the theme of special divine action. Can general divine action and special divine action be distinguished empirically? Is the concept of divine action - whether

${ }^{49}$ David M. Armstrong, What Is a Law of Nature? (Cambridge: Cambridge University Press, 1983).

${ }^{50}$ Frank P. Ramsey, 'Universals of Law and Fact', in Foundations, ed. by D. H. Mellor (London: Routledge \& Kegan Paul, 1978), pp. 128-32.

${ }^{51}$ Helen Beebee, 'The Non-Governing Conception of Laws of Nature', Philosophy and Phenomenological Research, 61 (2000), 571-94. For a response, see John T. Roberts, The Law-Governed Universe (Oxford: Oxford University Press, 2008).

${ }^{52}$ On the former, see Nancy Cartwright, The Dappled World: A Study of the Boundaries of Science (Cambridge, UK New York, NY: Cambridge University Press, 1999); 'God's Order, Man's Order and the Order of Nature', Euresis, 5 (2013), 99-108. On the latter, see Peter Lipton, 'All Else Being Equal', Philosophy, 74 (1999), 155-68.

${ }^{53}$ As pointed out by Nicholas Saunders, Divine Action and Modern Science, p. 62.

${ }^{54}$ Max Kistler, 'Laws of Nature, Exceptions and Tropes', Philosophia Scientiae, 7 (2003), 189-219; quotation at p. 192.

55 See, for example, Paul Gwynne, Special Divine Action: Key Issues in the Contemporary Debate, 1965-1995 (Rome: Pontificia Università Gregoriana, 1996), pp. 133-8. 
special or general - an objective reality or a subjective perception? ${ }^{56}$ There are certainly concerns about whether the distinction can be maintained beyond the level of normative definition. The concern here, however, goes deeper. How are we to understand the relation between theological depictions of the world as the locus of divine action and scientific descriptions of the world as an intelligible structure of natural law, based on empirical observation?

Divine action - whether special or general - is not observed, precisely because it is not observable. Events in the natural world are observed, which may be - but do not necessarily demand to be - interpreted as instances of divine action, whether general or special. The distinction between the two types of divine action is either to be grounded in the realm of theological a priori, or as a matter of intuition. The distinction between special and general divine action is somewhat intuitive. General divine action is normally intuited to mean something like God's 'usual' activity in creating and sustaining the whole world, including the establishment of the laws of nature. Special divine action could be defined in terms of God's 'extraordinary' or particular providential activity within the world, especially as it affects the course of human history and the lives of individual people. These distinctions do not arise, necessarily or plausibly, from the empirical observation of the natural world.

The language of special divine action is difficult, and perhaps impossible, to translate into the language and conceptualities of the natural sciences. Inevitably, this leads to the suggestion that contemporary debates about scientific perspectives on special divine action essentially amount to attempts to accommodate an essentially theological and non-empirical - notion within the conceptual interstices of a scientific understanding of the world. They add nothing to a scientific understanding of the world, and risk being seen merely as a parallel way of conceiving the world, along the lines of the unhelpful framework of 'non-overlapping magisteria' proposed by Stephen Jay Gould. ${ }^{57}$

Both these questions are capable of being engaged more fully, and we can look forward to some important discussions in the future. Yet we must now turn to a relatively neglected theme, as we consider how

${ }^{56}$ Paul Gwynne, Special Divine Action, p. 33. The 'subjective perception' thesis is developed in detail in Maurice F. Wiles, God's Action in the World (London: SCM Press, 1986).

${ }^{57}$ Stephen Jay Gould, 'Nonoverlapping Magisteria', Natural History, 106 (1997), 16-22. 
certain theological developments have had a significant impact on this discussion.

\section{THEOLOGICAL CONCERNS ABOUT SPECIAL DIVINE ACTION}

Earlier in this chapter, we noted Isaac Newton's reluctance to allow any form of divine intervention within the world. In part, this reflects his views on the causal structures of the world, expressed in his laws of motion. Yet it is important to note that Newton vigorously rejected a notion of God which entailed action within the world - namely, a Trinitarian conception of God. Newton's anti-Trinitarianism became well-known after his death, although he went to some pains to conceal it during his own lifetime. ${ }^{58}$ Although scholars have tended to focus on the rational and scientific motivations for this outlook, it is important to emphasise that this emphasis on the foundations of Newton's anti-Trinitarianism have led to a failure to deal adequately with its consequences.

Newton's views were, in certain ways, typical of his age. Most leading theologians of the seventeenth century seem to have held on to the doctrine of the Trinity out of respect for tradition, ${ }^{59}$ while privately conceding that it seemed irrational in the light of the growing emphasis upon the 'reasonableness of Christianity', and that it seemed to provide little in the way of spiritual or theological benefits. ${ }^{60}$ While simplifications are dangerous, defence of this doctrine seems to have been seen as being little more than a formal expectation on the part of orthodox theologians.

Why is this observation important? Because the doctrine of the Trinity provided an intellectual framework that safeguarded an active conception of God, providing a bulwark against a reduced generic notion of divinity which limited action to the creation and ordering of the world. The twentieth-century theologian Emil Brunner spoke of the Trinity as a 'security doctrine (Schutzlehre)', protecting Christian theology against deficient notions of God. ${ }^{61}$ The theological generations to follow Newton

58 The best study is Scott Mandelbrote, 'Eighteenth-Century Reactions to Newton's Anti-Trinitarianism', in Newton and Newtonianism: New Studies, pp. 93-112.

${ }^{59}$ Philip Dixon, Nice and Hot Disputes: The Doctrine of the Trinity in the Seventeenth Century (London: T \& T Clark, 2003).

${ }^{60}$ Paul Chang-Ha Lim, Mystery Unveiled: The Crisis of the Trinity in Early Modern England, Oxford Studies in Historical Theology (New York: Oxford University Press, 2012).

${ }^{61}$ Emil Brunner, Dogmatik I: Die christliche Lehre von Gott (Zürich: Zwingli-Verlag, 1959), p. 206. 
tended to adopt an essentially deist notion of God in their public defence of Christianity. Having set to one side an incarnational notion of God entering into the world, and any notion of the Holy Spirit as God's activity within the world, they were left with the notion of a God who designed and created the world, and thereafter ceased to be involved in it.

This is perhaps seen most clearly in William Paley's Natural Theology (1802), which speaks of God as an 'artificer' - that is, someone who designs and creates - but which pointedly declined to allow any further divine involvement with the natural order, even if this seemed to evacuate the concept of providence of any meaning. Paley was fascinated with the intricate structures of the human body and other biological organisms; ${ }^{62}$ nevertheless, he interpreted this in terms of God's past activity, which was taken to imply God's continuing existence. Paley's lack of interest in the concept of the Trinity - which, it must be noted, was representative of his age - denied him access to a concept of God which affirmed ongoing divine presence and activity within the world.

Today, the doctrine of the Trinity is central to Christian theological discourse. The work of theologians such as Karl Barth and Karl Rahner has led to a major exercise of theological retrieval, in which the doctrine of the Trinity has been reaffirmed, along with its implications for divine action and presence within the world. ${ }^{63}$ As we saw earlier, Christianity has always known and affirmed God as one who acts within the world; the problem was that the theology of the modern period adopted a rationally maximised notion of God which secured cultural compliance and conformity at the price of suppressing any expectation that God might act. The emergence of the Pentecostal movement in the twentieth century represents a further correction of this inadequate means of conceiving God.

So where does this leave us? It does not resolve the intellectual issues that we have noted in this paper about the plausibility of the notion of special divine action. Nevertheless, it does present us with a vision of God which encourages us to expect such action, and hence be more responsive towards developing frameworks within which such action may be accommodated. ${ }^{64}$ It also provides a framework for integrating

${ }^{62}$ Fernando Vidal, 'Extraordinary Bodies and the Physicotheological Imagination', in The Face of Nature in Enlightenment Europe, ed. by Lorraine Daston and Gianna Pomata (Berlin: Berliner Wissenschafts-Verlag, 2003), pp. 61-96.

${ }^{63}$ See Stephen T. Davis, Daniel Kendall, and Gerald O'Collins, eds., The Trinity: An Interdisciplinary Symposium on the Trinity (Oxford: Oxford University Press, 2002). 
general and special divine action, holding them together as notionally distinguishable yet functionally inseparable aspects of God's relationship with the world.

Yet there remain questions about the traction of a Trinitarian notion of God within western culture in general, and popular Christian culture in particular. Is this retrieval of Trinitarianism limited to academic theology, or has it a wider impact in popular Christianity? It is important to note that there are good reasons for thinking that a generalized and generic deism - similar to that of the 'Age of Reason' - has gained considerable influence in the west since the Second World War, partly as a means of positioning Christianity, Judaism, and Islam within a common theological matrix that enabled maximal social inclusivity.

Robert Bellah's observations about the emergence of 'American civil religion' during the 1960 s should be noted here. ${ }^{65}$ The phenomenon of civil religion requires maximum commonality, which in turn leads to an emphasis on the 'lowest common denominator' of religions and a corresponding de-emphasis of the distinctive features of - for example - a Trinitarian concept of God. This is not a cultural innovation, in that one of the original motivations for embracing a minimalist deism in seventeenth and eighteenth-century Europe was its potential for maximizing religious and social cohesion within religiously divided or variegated contexts. ${ }^{66}$ This 'civil religion' prefers to think of God as a moral legislator, rather than as someone who actively intervenes in the natural or social processes. ${ }^{67}$

A more recent development within American popular culture has been the adoption of what some have called a 'moralistic therapeutic deism' on the part of some younger Christians. ${ }^{68}$ This understanding

${ }^{64}$ See the points made in Christoph Schwoebel, God: Action and Revelation (Kampen: Kok Pharos, 1992), pp. 42-4; Andreas Loos, 'Divine Action and the Trinity: A Brief Exploration of the Grounds of Trinitarian Speech About God in the Theology of Adolf Schlatter', International Journal of Systematic Theology, 4 (2003), 255-77.

${ }^{65}$ Robert Bellah, 'Civil Religion in America', Daedalus, 96 (1967), 1-21.

${ }^{66}$ Ronald Beiner, 'Machiavelli, Hobbes, and Rousseau on Civil Religion', Review of Politics, 55 (1993), 617-38. Note also the issues explored by Patrick Giddy, 'Special Divine Action and How to Do Philosophy of Religion', South African Journal of Philosophy, 30 (2011), 143-54.

${ }^{67}$ See further Robert Corfe, Deism and Social Ethics: The Role of Religion in the Third Millennium (New York: Arena Books, 2007).

${ }^{68}$ This phrase was introduced by the sociologists Christian Smith and Melina Lundquist Denton, Soul Searching: The Religious and Spiritual Lives of American Teenagers (New York: Oxford University Press, 2005), pp. 118-71. 
of religion as a positive moral and therapeutic factor in life tends to marginalize the creedal and theological dimensions of faith, and speaks of divine intervention primarily - though not exclusively - in terms of the correction or amelioration of personal narratives. It remains unclear what the longer term influence of this trend may be, both in terms of its cultural influence and its potential impact on a future generation's reflections on the notion of special divine action.

\section{CONCLUSION}

The new interest in special divine action has led to a close reading of the great debates and discussions of the early modern period in an attempt to understand contemporary resistance to the notion of divine action, and to develop strategies for reaffirming the notion in a refined manner. Although continuing engagement with and evaluation of the Humean legacy on miracles and divine action will be of central importance to this programme of review, there are other issues that also need to be addressed. This article has tried to identify some of the factors that have caused or continue to cause difficulties for the articulation of a concept of special divine action and how they might be engaged, as a means of encouraging the conversation to move beyond the framework of the 'Divine Action Project' into new approaches and paradigms. 